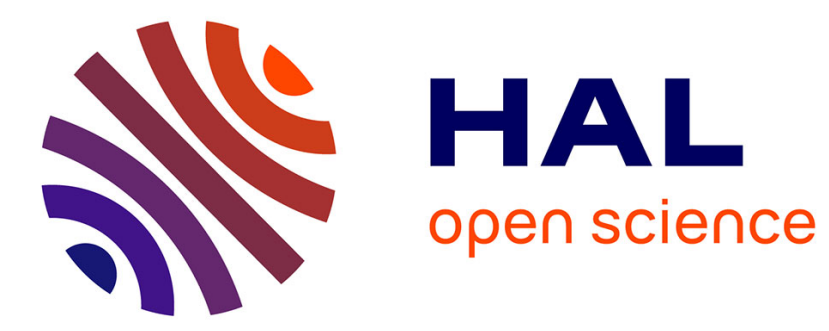

\title{
Serum cystatin C level in patients with rheumatoid arthritis after single infusion of infliximab
}

M. Kopec-Medrek, M. Widuchowska, A. Kotulska, E. Zycinska-Dębska, E. J. Kucharz

\section{- To cite this version:}

M. Kopec-Medrek, M. Widuchowska, A. Kotulska, E. Zycinska-Dębska, E. J. Kucharz. Serum cystatin $\mathrm{C}$ level in patients with rheumatoid arthritis after single infusion of infliximab. Rheumatology International, 2010, 31 (9), pp.1255-1256. 10.1007/s00296-010-1572-5 . hal-00618202

\section{HAL Id: hal-00618202 https://hal.science/hal-00618202}

Submitted on 1 Sep 2011

HAL is a multi-disciplinary open access archive for the deposit and dissemination of scientific research documents, whether they are published or not. The documents may come from teaching and research institutions in France or abroad, or from public or private research centers.
L'archive ouverte pluridisciplinaire HAL, est destinée au dépôt et à la diffusion de documents scientifiques de niveau recherche, publiés ou non, émanant des établissements d'enseignement et de recherche français ou étrangers, des laboratoires publics ou privés. 


\title{
SERUM CYSTATIN C LEVEL IN PATIENTS WITH RHEUMATOID ARTHRITIS AFTER SINGLE INFUSION OF INFLIXIMAB
}

M.Kopec-Medrek, M.Widuchowska, A.Kotulska, E.Zycinska-Dębska, E.J.Kucharz

\section{Department of Internal Medicine and Rheumatology \\ Medical University of Silesia \\ Katowice, Poland}

\begin{abstract}
Magdalena Kopec-Medrek
e-mail: magda.kopec@gazeta.pl

tel.:+48323598290
\end{abstract}

Sirs,

Rheumatoid arthritis (RA) is a chronic inflammatory disease that often leads to impairment of the kidney function. Cystatin $\mathrm{C}$ might be used as marker of early renal dysfunction, moreover it correlates better with GFR than serum creatinin level [1]. Mannge et al [2] reported that in a group of 56 patients with RA in $60 \%$ of patients serum cystatin C level was increased while only in 3 patient's serum creatinine level was increased.

The present study was designed to evaluate the effect of infliximab, anti-TNF- $\alpha$ antibody therapy on serum cystatin $\mathrm{C}$ level and its association with changes in creatinine, GFR, inflammatory indices (ESR, CRP) and DAS 28 in patients with RA with initially normal creatinine level.

Ten RF positive, postmenopausal, no smoking, without diabetes mellitus and hypertension women with RA aged $50.8 \pm 5.96$ yrs were investigated. Patients met the 1987 American College of Rheumatology (ACR) criteria for RA. Duration of RA $7.08 \pm$ 1.2 yrs. All patients were treated with infliximab $(3 \mathrm{mg} / \mathrm{kg}$ of body mass). Patients were also given prednisone in an unchanged. dose of $7.5 \pm 1.16 \mathrm{mg} / \mathrm{day}$ and methotrexate in a dose of $15 \mathrm{mg} /$ week. Some authors indicate [3] that change of the steroids dose might influence the serum cystatin $\mathrm{C}$ level. Blood samples were obtained at 8:00 AM after overning fasting, before and one day after the first infusion of infliximab. Serum cystatin C was assayed with ELISA (Human Cystatin C ELISA, Bio Vendor Laboratory Medicine, Inc.) before and after single infusion of infliximab. ESR, CRP, serum creatinine concentration (before and after treatment) were assayed with routine methods. 
DAS 28 was calculated with commonly used formula, glomerular filtration rate (GFR) was estimated by the Cockroft-Gault (CG) formula. The characteristic of the patients (ESR, CRP, DAS28, serum creatinine level and GFR) before and after the infusion of infliximab are shown in Table 1 . The results were expressed as mean \pm standard deviation (SD). Differences were tested for significance using the Student's t-test or the Wilcoxon test where appropriate. Correlations were assessed using Spearman's rank correlation.

The results are shown in Table 1. After one dose of infliximab there was a significant increase in mean cystatin C level. Creatinine level and GFR did not change significantly. There was a significant decrease in the disease activity (ESR, CRP, DAS 28). There was no statistical correlation between the evaluated parameters.

In the currently published literature the opinions on influence of inflammatory state on serum cystatin level are controversial. Karstila et al [4] did not find any influence of inflammatory parameters (CRP, ESR) on cystatin C levels. Knight et al.[1] shown that higher serum CRP levels are associated with higher serum cystatin $\mathrm{C}$ levels.

In contrast Bokarewa et al. [5] proved that in patients with RA there is relationship between serum cystatin $\mathrm{C}$ level and serum amyloid A level (SAA), an acute phase reactant. Cystatin $\mathrm{C}$ is thought to bind SAA and therefore its serum level might be decreased in patients with active RA.

Probably the increase in serum cystatin $\mathrm{C}$ level in patients with RA after one dose of infliximab in this study is caused by the decrease in serum SAA as a results of decrease of the inflammatory process [5] and is not dependent on the renal function. However there was no statistically significant correlation between serum cystatin $\mathrm{C}$ level and the acute phase reactants. Further investigations are required before firm conclusions can be drawn regarding the influence of infliximab on serum cystatin $\mathrm{C}$ level.

Disclosure of Interest: None declared. 
Table 1. Characteristics of the patients with rheumatoid arthritis before and after single infusion of infliximab (mean \pm standard deviation (SD)).

\begin{tabular}{|c||c|c|c|c|c|c|}
\hline $\begin{array}{c}\text { Investigated } \\
\text { group }\end{array}$ & ESR [mm/hr] & CRP [mg/l] & DAS 28 & $\begin{array}{c}\text { Serum } \\
\text { creatinine } \\
{[\mathrm{mg} / \mathrm{dl}]}\end{array}$ & $\begin{array}{c}\text { GFR } \\
(\text { Cockroft-Gault }) \\
{\left[\mathrm{ml} / \mathrm{min} / 1.73 \mathrm{~m}^{2}\right]}\end{array}$ & $\begin{array}{c}\text { Serum cystatin C } \\
{[\mathrm{ng} / \mathrm{ml}]}\end{array}$ \\
\hline $\begin{array}{c}\text { Before } \\
\text { infliximab }\end{array}$ & $40.2 \pm 29.75$ & $35.5 \pm 32.58$ & $6.24 \pm 1.35$ & $0.78 \pm 0.13$ & $97.7 \pm 27.56$ & $356.86 \pm 362.21$ \\
\hline $\begin{array}{c}\text { After } \\
\text { infliximab }\end{array}$ & $38.5 \pm 29.56^{*}$ & $30.46 \pm 28.85^{*}$ & $4.27 \pm 0.79 *$ & $0.79 \pm 0.16$ & $98.33 \pm 25.81$ & $406.70 \pm 369.61 *$ \\
\hline
\end{tabular}

Statistical significance of the difference from the corresponding group $* \mathrm{p}<0.05$ 
References:

1. Knight EL, Verhave JC, Spiegelman D, Hillege HL, de Zeeuw D, Curhan GC, de Jong PE (2004) Factors influencing serum cystatin C levels other than renal function and the impact on renal function measurement. Kidney Int 65: 1416-1421.

2. Mangge H, Liebmann P, Tanil H, Herrmann J, Wagner C, Gallistl S, Schauenstein K, Erwa W (2000) Cystatin C, an early indicator for incipiens renal diseases in rheumatoid arthritis. Clin Chim Acta 300: 195-202.

3. Risch L, Herklotz R, Blumberg A, Huber AR (2001) Effects of glucocorticoid immunosuppression on serum cystatin $\mathrm{C}$ concentrations in renal transplant patients. Clin Chem 47: 2055-2059.

4. Karstila K, Harmoinen APT, Lehtimäki TJ, Korpela MM, Mustonen JT, Saha HHT (2008) Measurement of the Kidney Function in patients with Rheumatoid Arthritis: Plasma Cystatin C versus Cr-EDTA Clearance. Nephron Clin Pract 108: 284290.

5. Bokarewa M, Abrahamson M, Levshin N, Egesten A, Grubb A, Dahlberg L, Tarkowski A (2007) Cystatin C binds serum amyloid A, downregulating its cytokinegenerating properties. J Rheumatol 34: 1293-1301. 